\title{
MicroRNA-210 negatively regulates the radiosensitivity of nasopharyngeal carcinoma cells
}

\author{
BO-YI LI ${ }^{1 *}$, YI LUO $^{1 *}$, WEN-SI ZHAO ${ }^{1}$, LU ZHANG $^{1}$, HAN-JING ZHOU ${ }^{1}$, YU-CHUN ZOU ${ }^{2}$ and TAO ZHANG ${ }^{1}$ \\ ${ }^{1}$ Department of Oncology, First Affiliated Hospital of Chongqing Medical University, Chongqing 400016; \\ ${ }^{2}$ Department of Oncology, Shizhu County People's Hospital, Chongqing 409100, P.R. China
}

Received March 2, 2016; Accepted March 16, 2017

DOI: $10.3892 / \mathrm{mmr} .2017 .6694$

\begin{abstract}
Radiotherapy is one of the primary methods of treatment of malignant tumors, however, resistance to radiation is a major problem. The reasons for the radioresistance are still poorly understood. However, it is generally accepted that microRNAs (miRNAs or miRs) can regulate the radiosensitivity of tumors. The present study therefore aimed to identify specific miRNAs and their effects on radioresistant cells. More specifically, the aim was to investigate specific miRNAs and their effects on radioresistant tumor cells. The radioresistant tumor cells (CNE-2R) were established using a dose gradient method, and the miRNA expression profiles of CNE-2R cells and the parental cells (CNE-2) were determined. The expression of miR-210 in CNE-2R cells was significantly higher than in CNE-2 cells. CNE-2R cells were transfected with LV-hsa-miR-210-inhibitor, and CNE-2 cells were transfected with LV-hsa-miR-210. The expression of miR-210 was confirmed by reverse transcription quantitative-polymerase chain reaction. The percentages of CNE-2R-miR-210-inhibitor and CNE-2 cells in the $\mathrm{G}_{2} / \mathrm{M}$ phase were higher than in the CNE-2R and CNE-2-miR-210 cells, and the percentages of cells in $\mathrm{S}$ phase were lower than in the CNE-2R and CNE-2-miR-210 cells. Following 4 Gy of radiation, CNE-2R-miR-210-inhibitor and CNE-2 cells, which express low levels of miR-210, had a higher apoptosis rate than $\mathrm{CNE}-2 \mathrm{R}$ and $\mathrm{CNE}-2-\mathrm{miR}-210$ cells. Following 4,8 and 12 Gy of radiation, cell viability and survival fraction of CNE-2R-miR-210-inhibitor cells were lower than those of CNE-2R and CNE-2-miR-210 cells, and similar to those of CNE-2 cells. Together, these findings strongly suggest that miR-210 negatively regulates the radiosensitivity of tumor cells, and may therefore have therapeutic potential for the treatment of radiation resistance.
\end{abstract}

Correspondence to: Professor Tao Zhang, Department of Oncology, First Affiliated Hospital of Chongqing Medical University, 1 Youyi Road, Yuzhong, Chongqing 400016, P.R. China E-mail: tumorzzt@163.com

*Contributed equally

Key words: miR-210, sensitivity, radioresistance, radiotherapy

\section{Introduction}

Presently, the primary treatments of cancer include surgery, radiotherapy, chemotherapy and targeted therapy. Radiotherapy is the main treatment used for cancer (1). It is widely used for the treatment of tumors in rectal cancer, non-small cell lung cancer and breast cancer (2-4).

For example, radiotherapy is the preferred and primary treatment for nasopharyngeal cancer (NPC) (5). Following radiotherapy, the five-year survival percentage for patients with NPC has increased from 50-60\% to a current percentage of $\sim 70 \%$. However, following radical radiotherapy, $\sim 20 \%$ of NPC patients still have residual tumors (6). Local treatment failure and distant metastasis are the key factors which prevent therapeutic efficacy, and intrinsic or acquired radiation resistance is one of the primary reasons causing the failure of radiotherapy and worse treatment outcomes $(7,8)$.

Thus, it is important to gain further insights into the molecular mechanisms of chemotherapeutic drug resistance, and find novel strategies involving improved therapeutic benefits for cancer patients.

microRNAs (miRNAs) are a class of small RNAs with an approximate length of 19-25 nucleotides, which are endogenous short noncoding RNAs (9). miRNAs bind to the 3'-untranslated region of target mRNAs, followed by degradation of the mRNA or inhibition of its translation. They may also regulate the expression of target genes at the post-transcriptional level (10), and are associated with regulating cell growth, proliferation, differentiation and apoptosis (11). miRNAs are observed in many cancers, and are involved in malignant tumor development and progression (12). Several studies have reported that the expressions of miRNAs are closely associated with the radiosensitivity of tumors, and upregulated or downregulated expression of miRNAs can increase tumor radiosensitivity (13). To address these possibilities, the following study characterized the effects of miRNAs on the radiation resistance of tumor cells, in order to provide a biochemical basis for further studies, which may use this biomarker to predict the radiosensitivity of cancer patients.

\section{Materials and methods}

Cells and cell culture. The CNE-2 cell line, which is suspected to be identical to CNE-1 and cross-contaminated with HeLa 
(cervical carcinoma) as well as an additional unknown cell line (14), was cultured in RPMI 1640 medium (Gibco; Thermo Fisher Scientific, Inc., Waltham, MA, USA) supplemented with $10 \%$ fetal bovine serum (Gibco; Thermo Fisher Scientific, Inc.), $1 \%$ penicillin-streptomycin (Sigma-Aldrich; Merck KGaA, Darmstadt, Germany) and grown at $37^{\circ} \mathrm{C}$ in an incubator with an atmosphere of $5 \% \mathrm{CO}_{2}$.

Development of acquired radioresistant cells. CNE-2 cells were cultured in $25 \mathrm{~cm}^{2}$ culture flasks. The cells were exposed to a series of increasing X-ray doses using a medical electronic linear accelerator (Varian Medical Systems, Palo Alto, CA, USA), in order to establish the radiation resistant tumor cells (CNE-2R). The distance of the source was $100 \mathrm{~cm}$, and the radiation field was $10 \times 10 \mathrm{~cm}$ at a dose rate of $300 \mathrm{cGy} / \mathrm{min}$. Cells were irradiated twice with $2 \mathrm{~Gy}$, four times with $4 \mathrm{~Gy}$, and five times with 6 Gy with X-ray radiation over a period of 6 months, so that the CNE-2 cells were exposed to a total dose of $50 \mathrm{~Gy}$. Following several cell passages, the radiation resistant tumor cells were established.

Apoptosis assay. The cells were radiated with 0 and 4 Gy of radiation. Following $12 \mathrm{~h}$, many cells were detached with trypsin without the use of EDTA. Cells were harvested in culture medium and centrifuged for $5 \mathrm{~min}$ at $300 \mathrm{x} \mathrm{g}$, and $1 \times 10^{5}$ cells were treated with $5 \mu \mathrm{l}$ Annexin V/PE and $10 \mu \mathrm{l}$ 7-AAD (BD Biosciences, Franklin Lakes, NJ, USA). The cells were gently vortexed and incubated for $15 \mathrm{~min}$ at room temperature in the dark. A total of $400 \mu \mathrm{l} 1 \mathrm{X}$ binding buffer was added into solution, the cells were analyzed using a Gallios flow cytometer (Beckman Coulter, Inc., Brea, CA, USA).

Cell cycle assay. The cells were digested with trypsin, and were centrifuged for $5 \mathrm{~min}$ at $300 \mathrm{x} \mathrm{g}$. Then the cells were resuspended twice with $2 \mathrm{ml} \mathrm{PBS}$, fixed with $1 \mathrm{ml} 70 \%$ ice cold ethanol, and stored at $4^{\circ} \mathrm{C}$ overnight. Then $100 \mu \mathrm{g} / \mathrm{ml}$ RNase and $50 \mu \mathrm{g} / \mathrm{ml}$ PI were added, and following incubation in the dark for $30 \mathrm{~min}$, the cell cycle was detected using a Gallios flow cytometer.

Cell viability assay. The cells $\left(5 \times 10^{3}\right)$ were seeded into 96-well plates. After the cells adhered to the plate, they were irradiated with different doses of X-ray radiation using $0,4,8$ and $12 \mathrm{~Gy}$, followed by incubation for $24 \mathrm{~h}$. Medium $(100 \mu \mathrm{l})$ was mixed with $10 \mu \mathrm{l}$ of CCK-8 solution (Dojindo Molecular Technologies, Inc., Kumamoto, Japan), and a total of $110 \mu 1$ of the mixed solution was added to each well, followed by incubation of the cells for $2 \mathrm{~h}$. The absorbance at $450 \mathrm{~nm}$ of the cells was then read using a microplate reader (Tecan Group Ltd., Männedorf, Switzerland).

Colony formation assay. The surviving cells were characterized using a colony formation assay. Two hundred cells were seeded into six-well plates. After the cells adhered, they were exposed to X-ray radiation with single doses of $0,4,8$ and $12 \mathrm{~Gy}$, and the cells were incubated for 2 weeks without disturbance. After 2 weeks, there were $>50$ cells in each colony. The cells were fixed with $4 \%$ paraformaldehyde for $30 \mathrm{~min}$ and stained with crystal violet solution for $30 \mathrm{~min}$, and the colonies counted. The percentage of cell survival was calculated as follows: The numbers of colonies at $\mathrm{x} \mathrm{Gy/(the}$ numbers of cells seeded at a $\mathrm{x}$ Gy colony forming rate).

MicroRNA microarray analysis. CapitalBio Technology Co., Ltd. (Beijing, China) conducted the present study's Agilent Human miRNA microarrays, which were 8x60 K microarrays used for detecting miRNA expression profiles of the CNE-2 and CNE-2R cells. There were many differential expressions of miRNAs using the microRNA microarray. Among these differential expressions, miR-210 had a significant fold change and a high probe signal, so miR-210 was chosen for further assays. Differences of miR-210 in the CNE-2 and CNE-2R cells were measured by RT-qPCR.

Overexpression of $\mathrm{miR}-210$ in CNE-2 cells and downregulation of miR-210 in CNE-2R cells. CNE-2R cells were transfected with LV-hsa-miR-210-inhibitor, which is a lentivirus inhibiting miR-210 loaded with green fluorescent protein (GFP; GeneChem Co., Ltd., Shanghai, China), and CNE-2 cells were transfected with LV-hsa-miR-210 + GFP, which is a lentivirus expressing miR-210 (GeneChem Co., Ltd.). Following infection with the virus, the infected cells were screened by puromycin for 1 month to establish stable downregulated and upregulated cells. Overexpression of miR-210 in CNE-2 cells resulted in CNE-2-miR-210 cells, and downregulation of miR-210 in CNE-2R cells resulting in CNE-2R-miR-210-inhibitor cells.

$R T-q P C R$. Total cellular RNA was extracted with TRIzol reagent (Invitrogen; Thermo Fisher Scientific, Inc., Waltham, MA, USA), then the RNA samples were used for cDNA synthesis using an All-in-One ${ }^{\mathrm{TM}}$ miRNA First-Strand cDNA Synthesis kit (GeneCopoeia, Inc., Rockville, MD, USA). miR-210 was detected with RT-qPCR by the All-in-One ${ }^{\mathrm{TM}}$ miRNA RT-qPCR kit (GeneCopoeia, Inc.). U6 was used as the control for detection of miR-210. The miR-210 RT-qPCR primer was purchased from GeneCopoeia, Inc. All steps followed the manufacturer's protocols. The results were calculated using the $2^{-\Delta \Delta C q}$ method (15).

Statistical analysis. SPSS software (version, 19.0; IBM SPSS, Armonk, NY, USA) was used for all the statistical analyses. One-way analysis of variance with Student-Newman-Keuls post hoc tests for multiple comparisons or a Student's t-test were used for the appropriate types of data. $\mathrm{P}<0.05$ was considered to indicate a statistically significant difference.

\section{Results}

Radiosensitivity of the CNE-2R cells. To verify whether the radioresistant tumor cells were established, the radiosensitivity of the CNE-2R cells was compared with the parental cells. The percentage of CNE- 2 cells in $\mathrm{G}_{2} / \mathrm{M}$ phase was significantly greater than $\mathrm{CNE}-2 \mathrm{R}$ cells (Fig. $1 \mathrm{~A} ; \mathrm{P}<0.05$ ). At the same time, determination of cell viabilities indicated that the CNE-2R cells had lower decreases in viability than the CNE-2 cells when irradiated with 4, 8 and 12 Gy of radiation (Fig. 1B; P<0.05). Furthermore, the radiosensitivities of the CNE-2 and CNE-2R cells were compared using the colony formation assay, which reported that the CNE-2R cells had a greater percentage of radioresistant cells than the CNE-2 
A

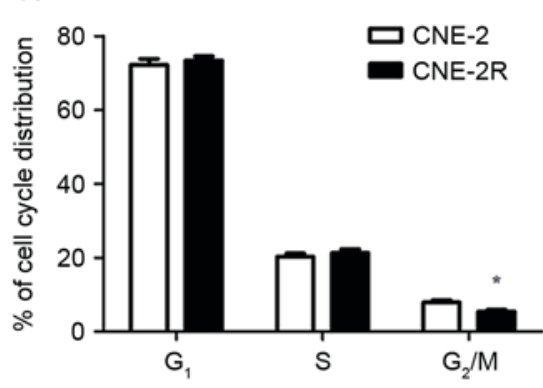

B



C

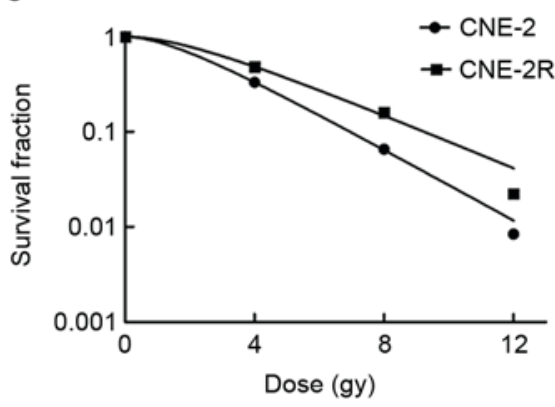

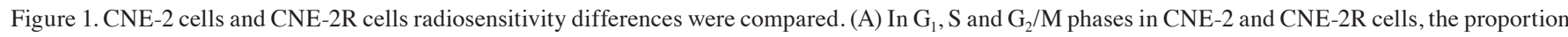
of CNE-2R cells in the $\mathrm{G}_{2} / \mathrm{M}$ phase were decreased. (B) Cell viability assay results to compare viability of CNE- 2 and $\mathrm{CNE}-2 \mathrm{R}$ cells. Results indicated a significant increase in viability of CNE-2R cells. (C) The data illustrated that CNE-2R cells had a higher survival fraction. Survival fractions were calculated as described above based on the data from colony formation assay. Data are the means \pm standard error of the mean. Three independent experiments were performed. ${ }^{*} \mathrm{P}<0.05,{ }^{* *} \mathrm{P}<0.01$ vs. $\mathrm{CNE}-2$ cells.

cells (Fig. 1C). These results demonstrated that the CNE-2R cells were more radioresistant than the CNE-2 cells, and that radioresistant tumor cells were established using the stated protocol.

Expression of miRNAs and $R T-q P C R$ verification between the CNE-2 cells and CNE-2R cells. Microarray analyses were used to compare the patterns of miRNA expression between the acquired radioresistant CNE-2R cells and their parental CNE- 2 cells. There were 92 miRNAs with expression changes greater than 2-fold in CNE-2R cells, involving 60 miRNAs that were upregulated and 32 miRNAs that were downregulated (Table I). The expression of miR-210 in CNE-2R cells was 247.25-fold higher than the expression in CNE-2 cells $(\mathrm{P}=0.0006)$.

Downregulation of $\mathrm{miR}-210$ in $C N E-2 R$ cells and overexpression of miR-210 in CNE-2 cells. In order to determine the relationship between miR-210 and radioresistance, the authors transfected LV-hsa-miR-210 into CNE-2 cells (Fig. 2A), and transfected the LV-hsa-miR-210-inhibitor into CNE-2R cells (Fig. 2B). Following infection for 72 h, 95\% of the CNE-2R cells and $95 \%$ of the CNE-2 cells expressed green fluorescent protein, as assessed with a fluorescence microscope. Next, the expressions of miR-210 in CNE-2R-miR-210-inhibitor and CNE-2-miR-210 cells were measured by RT-qPCR. The expression of miR-210 in CNE-2-miR-210 cells was significantly greater than $\mathrm{CNE}-2$ cells (Fig. 3A; $\mathrm{P}<0.05$ ), and the expression of miR-210 was significantly lower in CNE-2R-miR-210-inhibitor cells compared to CNE-2R cells (Fig. 3B; $\mathrm{P}<0.05)$. Consistent with these expected results, downregulation of miR-210 expression in CNE-2R cells and overexpression in CNE-2 cells was identified.

Correlation of miR-210 expression levels with cell cycle and apoptosis in tumor cells. Low expression of miR-210 in CNE-2 cells, there was a significant decrease in the percentage of cells in $\mathrm{S}$ phase, and a significant increase in the percentage of cells in $\mathrm{G}_{2} / \mathrm{M}$ phase, when compared with CNE-2-miR-210 cells (Fig. 4A; $\mathrm{P}<0.05$ ). In addition to the low expression of miR-210 in CNE-2R-miR-210-inhibitor cells leading to a significant decrease in the percentage of cells in $\mathrm{S}$ phase, there was a significant increase in the percentage of CNE-2R-miR-210-inhibitor cells in $\mathrm{G}_{2} / \mathrm{M}$ phase when compared with the control CNE-2R cells (Fig. 4B, $\mathrm{P}<0.05$ ). The authors exposed cells to 0 or $4 \mathrm{~Gy}$ of $\mathrm{X}$-ray radiation, and apoptosis was measured by flow cytometry. The results of flow cytometry indicated that the apoptosis percentage of CNE-2-miR-210 cells was significantly lower than CNE-2 cells (Fig. 5A; $\mathrm{P}<0.05$ ), and the apoptosis percentage of CNE-2R-miR-210-inhibitor cells was significantly greater than $\mathrm{CNE}-2 \mathrm{R}$ cells (Fig. 5B; $\mathrm{P}<0.05$ ), following irradiation by $4 \mathrm{~Gy}$. However, there were no significant differences in the percentages of apoptosis of these cells in the absence of irradiation (Fig. 5A and B).

miR-210 negatively regulates cell viability following irradiation. To determine whether miR-210 negatively regulates cell viability, a cell viability assay was used to determine the effect of miR-210 on cell viability with different doses of X-ray radiation of $0,4,8$ and $12 \mathrm{~Gy}$. The cell viability of CNE-2 cells was lower than CNE-2-miR-210 cells when they were radiated with 4,8 and 12 Gy (Fig. 6A; $\mathrm{P}<0.05)$. The cell viability of $\mathrm{CNE}-2 \mathrm{R}$ cells was higher than CNE-2R-miR-210-inhibitor cells following being irradiated by 4,8 and 12 Gy (Fig. 6B; $\mathrm{P}<0.05$ ), demonstrating that suppression of miR-210 expression increased the viability of tumor cells.

miR-210 promotes the radioresistance of tumor cells. In order to identify and confirm that miR-210 promotes radioresistance of tumor cells, the authors irradiated CNE-2, CNE-2R, CNE-2-miR-210 and CNE-2R-miR-210-inhibitor cells with different doses of $\mathrm{X}$-ray radiation of $0,4,8$ and $12 \mathrm{~Gy}$, and determined the cell survival using a colony formation assay (Fig. 7). As expected, the CNE-2 cells were more radiosensitive than $\mathrm{CNE}-2-\mathrm{miR}-210$ cells following $\mathrm{X}$-ray treatment, and CNE-2R cells were more radioresistant than the CNE-2R-miR-210-inhibitor cells, confirming that miR-210 can promote radioresistance of tumor cells.

Target gene analysis. It was predicted that miRNAs exerted their functions via regulating the expression of the target genes miRbase (http://mirbase.org/index.shtml), miRecords 
Table I. Differential expression of miRNAs in CNE-2 and CNE-2R cells.

Table I. Continued.

\begin{tabular}{|c|c|c|c|}
\hline No. & miRNA & $\begin{array}{c}\text { Fold } \\
\text { change }^{\mathrm{a}} \\
(\log 2)\end{array}$ & $\mathrm{P}$-value \\
\hline 50 & miR-629-3p & 2.002 & 0.0051 \\
\hline 51 & miR-629-5p & 53.444 & 0.0066 \\
\hline 52 & miR-6510-5p & 95.523 & 0.0110 \\
\hline 53 & miR-6512-5p & 2.148 & 0.0098 \\
\hline 54 & miR-6514-3p & 118.251 & 0.0109 \\
\hline 55 & miR-6515-3p & 90.446 & 0.0230 \\
\hline 56 & $\operatorname{miR}-664 b-3 p$ & 64.357 & 0.0080 \\
\hline 57 & $\operatorname{miR}-6716-3 p$ & 32.462 & 0.0102 \\
\hline 58 & miR-766-3p & 50.140 & 0.0077 \\
\hline 59 & miR-940 & 55.310 & 0.0220 \\
\hline 60 & miR-95 & 2.049 & 0.0035 \\
\hline 61 & miR-1224-5p & 2.115 & 0.0089 \\
\hline 62 & $\operatorname{miR}-125 a-3 p$ & 3.413 & 0.0113 \\
\hline 63 & miR-1268a & 3.235 & 0.0248 \\
\hline 64 & miR-1268b & 2.005 & 0.0016 \\
\hline 65 & miR-1275 & 2.876 & 0.0105 \\
\hline 66 & miR-1287 & 2.052 & 0.0077 \\
\hline 67 & miR-1290 & 4.105 & 0.0080 \\
\hline 68 & miR-135a-3p & 40.335 & 0.0211 \\
\hline 69 & miR-188-5p & 2.468 & 0.0370 \\
\hline 70 & miR-21-3p & 2.590 & 0.0087 \\
\hline 71 & miR-22-5p & 2.110 & 0.0112 \\
\hline 72 & miR-221-3p & 2.293 & 0.0099 \\
\hline 73 & miR-221-5p & 2.174 & 0.0115 \\
\hline 74 & miR-3135b & 3.459 & 0.0063 \\
\hline 75 & miR-3648 & 2.135 & 0.0061 \\
\hline 76 & miR-3656 & 3.438 & 0.0124 \\
\hline 77 & miR-3679-5p & 2.105 & 0.0035 \\
\hline 78 & miR-4298 & 86.930 & 0.0039 \\
\hline 79 & miR-4455 & 7.343 & 0.0091 \\
\hline 80 & miR-4459 & 2.076 & 0.0022 \\
\hline 81 & miR-4466 & 2.209 & 0.0231 \\
\hline 82 & miR-4485 & 2.076 & 0.0103 \\
\hline 83 & miR-4487 & 2.446 & 0.0007 \\
\hline 84 & miR-4532 & 3.176 & 0.0176 \\
\hline 85 & $\operatorname{miR}-4672$ & 2.512 & 0.0233 \\
\hline 86 & miR-483-5p & 91.404 & 0.0145 \\
\hline 87 & miR-5001-5p & 2.079 & 0.0069 \\
\hline 88 & miR-574-5p & 3.520 & 0.0201 \\
\hline 89 & miR-5787 & 6.642 & 0.0088 \\
\hline 90 & miR-6087 & 3.059 & 0.0121 \\
\hline 91 & $\operatorname{miR}-642 a-3 p$ & 2.042 & 0.0084 \\
\hline 92 & miR-663a & 156.200 & 0.0092 \\
\hline
\end{tabular}

${ }^{a} \mid$ Fold changel $>2$ is listed; fold change equals resistance/parental.

change $^{\mathrm{a}}$

No.

\section{1}

2

3

4

\begin{tabular}{|c|c|c|}
\hline miRNA & $\begin{array}{c}\text { Fold } \\
\text { change }^{a} \\
(\log 2)\end{array}$ & P-value \\
\hline miR-105-5p & 28.179 & 0.0032 \\
\hline miR-1228-3p & 98.961 & 0.0172 \\
\hline miR-1228 & 97.514 & 0.0042 \\
\hline miR-130a-3p & 2.396 & 0.0901 \\
\hline miR-149-5p & 44.556 & 0.0503 \\
\hline miR-181d & 43.655 & 0.0082 \\
\hline miR-182-5p & 35.525 & 0.0260 \\
\hline miR-192-5p & 107.700 & 0.0081 \\
\hline miR-194-5p & 40.462 & 0.0206 \\
\hline miR-197-3p & 2.151 & 0.0095 \\
\hline miR-210 & 247.250 & 0.0006 \\
\hline miR-212-3p & 51.685 & 0.0225 \\
\hline miR-296-5p & 40.781 & 0.0304 \\
\hline $\operatorname{miR}-301 b$ & 19.520 & 0.0087 \\
\hline miR-3132 & 112.260 & 0.0059 \\
\hline miR-3162-3p & 207.030 & 0.0203 \\
\hline miR-338-3p & 4.461 & 0.0048 \\
\hline miR-340-5p & 39.523 & 0.0076 \\
\hline miR-342-3p & 2.702 & 0.0095 \\
\hline miR-34a-3p & 48.242 & 0.0207 \\
\hline miR-34b-3p & 41.055 & 0.0190 \\
\hline miR-3591-3p & 142.980 & 0.0303 \\
\hline miR-361-3p & 95.404 & 0.0040 \\
\hline miR-3653 & 64.164 & 0.0073 \\
\hline miR-3663-3p & 157.820 & 0.0206 \\
\hline miR-3940-5p & 52.816 & 0.0104 \\
\hline miR-4254 & 141.580 & 0.0065 \\
\hline miR-4433-5p & 106.840 & 0.0081 \\
\hline miR-4449 & 61.067 & 0.0009 \\
\hline miR-4478 & 40.268 & 0.0054 \\
\hline miR-4484 & 65.965 & 0.0070 \\
\hline $\operatorname{miR}-451 b$ & 211.190 & 0.0009 \\
\hline miR-452-5p & 153.160 & 0.0013 \\
\hline miR-454-3p & 65.327 & 0.0305 \\
\hline miR-4634 & 81.783 & 0.0097 \\
\hline miR-4649-3p & 69.214 & 0.0063 \\
\hline miR-4665-3p & 85.470 & 0.0130 \\
\hline miR-4701-5p & 142.820 & 0.0066 \\
\hline miR-4730 & 31.110 & 0.0411 \\
\hline miR-4787-5p & 64.610 & 0.0225 \\
\hline miR-484 & 81.568 & 0.0020 \\
\hline miR-5010-3p & 119.350 & 0.0145 \\
\hline miR-503-5p & 67.102 & 0.0176 \\
\hline miR-5100 & 2.127 & 0.0105 \\
\hline miR-517c-3p & 62.576 & 0.0067 \\
\hline miR-521 & 58.890 & 0.0112 \\
\hline miR-522-3p & 108.351 & 0.0054 \\
\hline miR-532-3p & 65.069 & 0.0092 \\
\hline miR-572 & 56.282 & 0.0132 \\
\hline
\end{tabular}




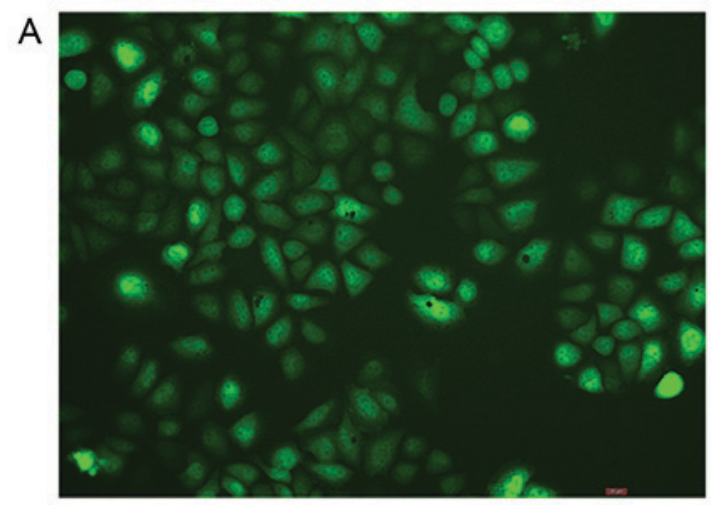

CNE-2-miR-210

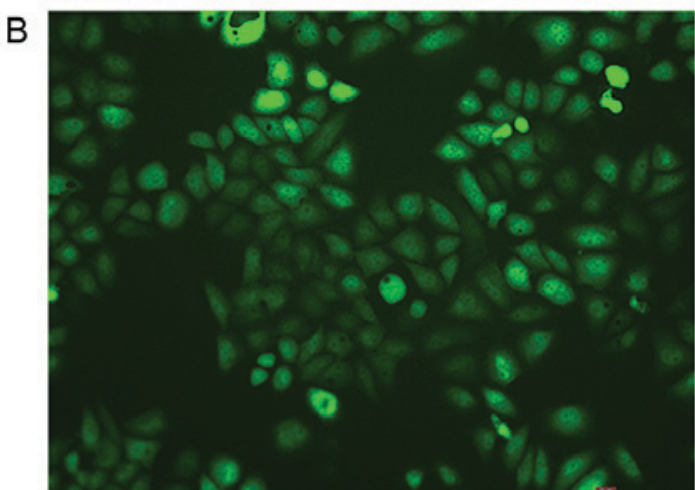

CNE-2R-miR-210-inhibitor

Figure 2. Photomicrographs presented tumor cells transfected with lentivirus. (A) CNE-2 cells were infected with LV-hsa-miR-210 and (B) CNE-2R cells were infected with LV-hsa-miR-210-inhibitor. Magnification, x200.

A

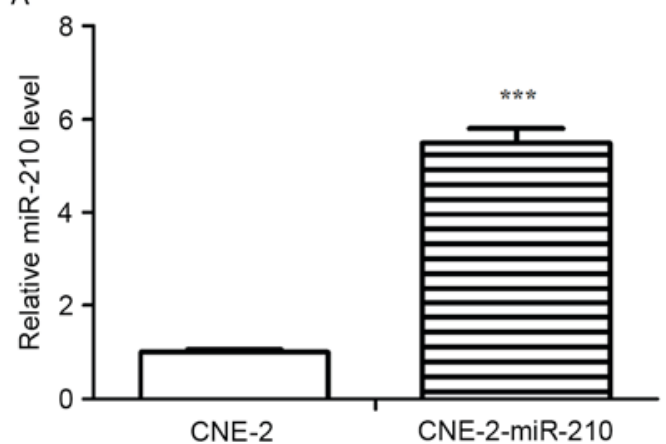

B

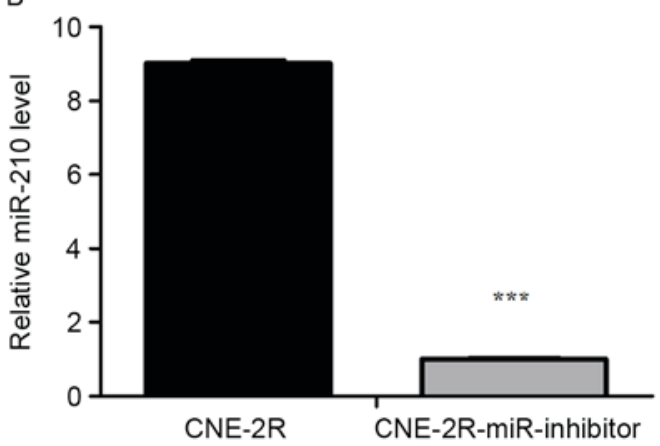

Figure 3. The expressions of miR-210 in CNE-2-miR-210 and CNE-2R-miR-210-inhibitor cells were measured by reverse transcription-quantitative polymerase chain reaction. (A) The expression of miR-210 in CNE-2-miR-210 cells was significantly greater than CNE-2 cells. ${ }^{* * *} \mathrm{P}<0.001$ vs. CNE-2. (B) The expression of miR-210 was significantly lower in CNE-2R-miR-210-inhibitor cells compared to CNE-2R cells. ${ }^{* * *} \mathrm{P}<0.001$ vs. CNE-2R. Data are the mean \pm standard errors of the mean. Three independent experiments were performed.

A

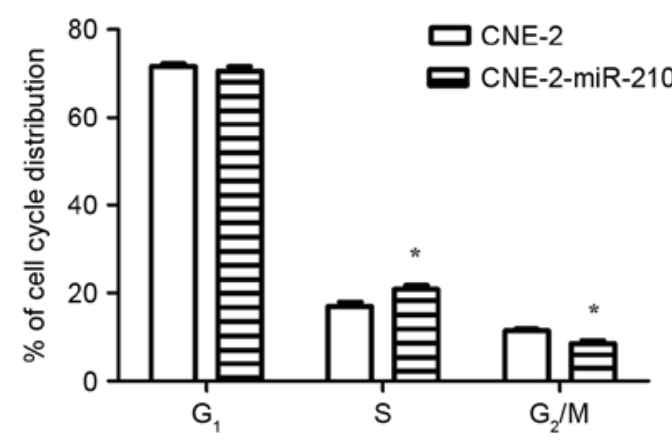

B

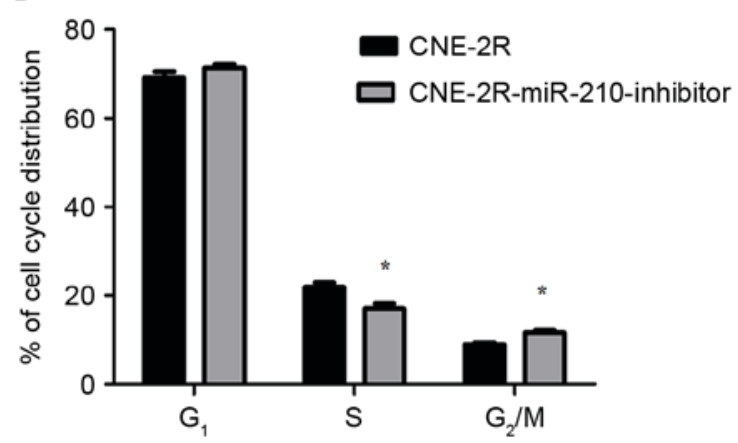

Figure 4. Cell cycle distribution. (A) There was a significant increase in the percentage of CNE-2-miR-210 cells in the S phase, and a significant decrease in the percentage of cells in the $\mathrm{G}_{2} / \mathrm{M}$ phase, when compared with $\mathrm{CNE}-2$-miR-210 cells. (B) CNE-2R-miR-210-inhibitor cells led to a significant decrease in the percentage of cells in the $\mathrm{S}$ phase, and increase in the percentage of CNE-2R-miR-210-inhibitor cells in the $\mathrm{G}_{2} / \mathrm{M}_{\text {phase }}$ when compared with the $\mathrm{CNE}_{\mathrm{N}}-2 \mathrm{R}$ cells. Data are the mean \pm standard error of the mean. ${ }^{*} \mathrm{P}<0.05$ vs. CNE-2. Three independent experiments were performed.

There were many potential target genes, such as $H I F-1 \alpha$, CTR1A, ADAMTS5 and CAMTA1. In future studies, the authors will use the luciferase reporter to identify target genes, and western blot analyses to detect differences in the translation products of these target genes. Furthermore, it is planned to characterize the mechanism of target gene radiosensitivity.

\section{Discussion}

Radiotherapy has emerged as the most important treatment for tumor, because it inhibits tumor growth and prolongs patient survival $(16,17)$. Radiotherapy, which primarily involves the induction of DNA damage, is the most common therapeutic method for many types of cancers (18). Numerous studies 
A

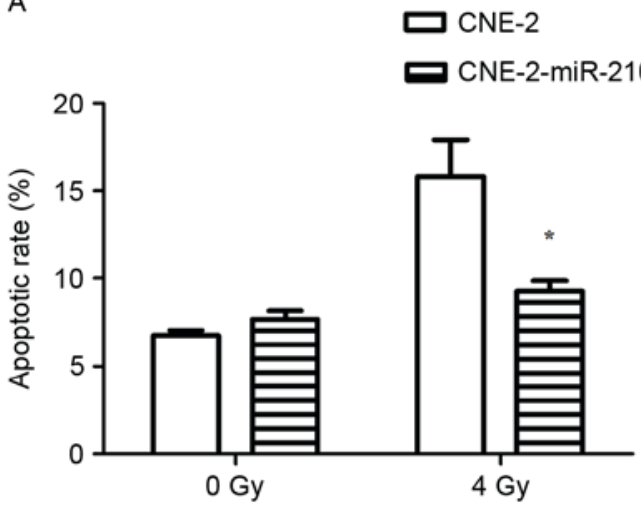

B

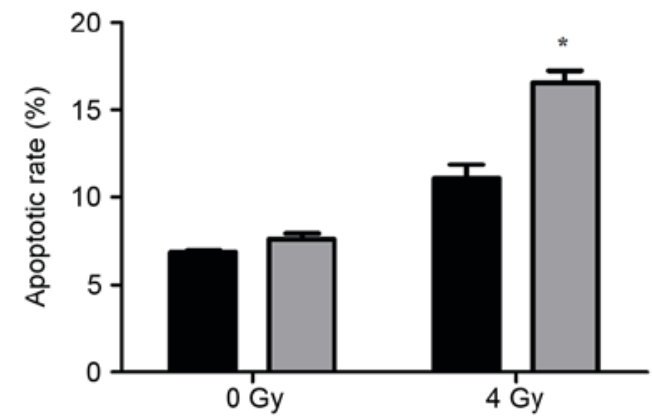

Figure 5. Assessment of apoptosis of cells treated with 0 or 4 Gy using Annexin V-PE/7-AAD staining. (A) Assessment of apoptosis of CNE-2 and CNE-2-miR-210 cells treated with 0 or 4 Gy using Annexin V-PE/7-AAD staining. ${ }^{*} \mathrm{P}<0.05$ vs. CNE-2. (B) Assessment of apoptosis of CNE-2R and CNE-2R-miR-210-inhibitor cells treated with 0 or 4 Gy using Annexin V-PE/7-AAD staining. ${ }^{*} \mathrm{P}<0.05$ vs. CNE-2R. Data are the means \pm standard error of the mean. Three independent experiments were performed.
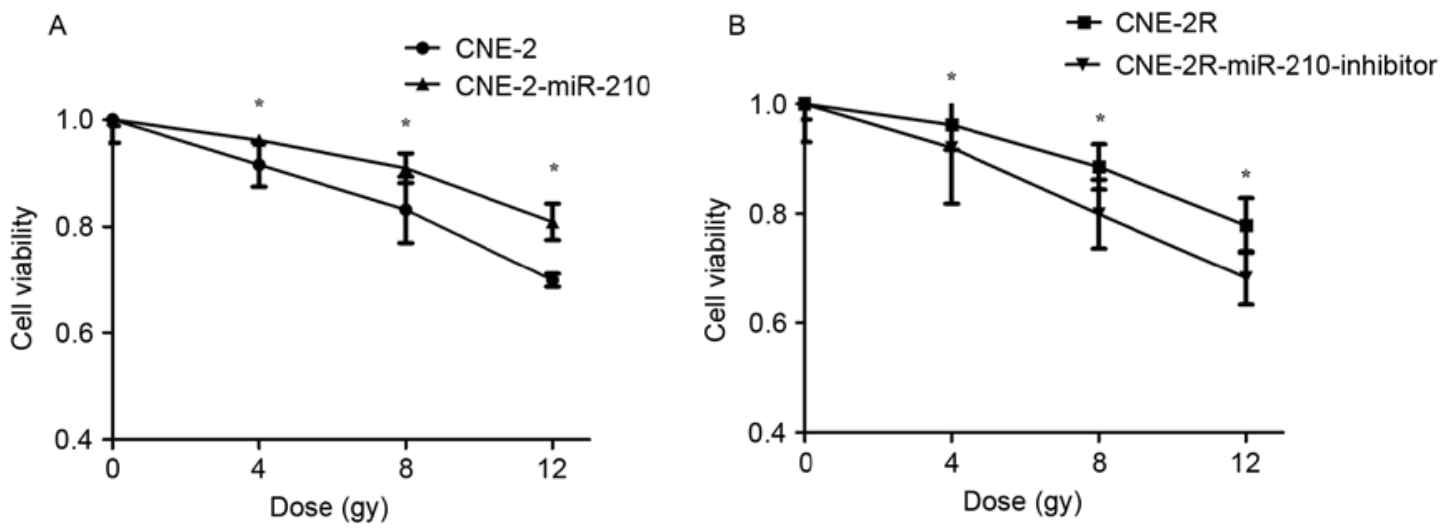

Figure 6. Cell viability assay. (A) Results to assess and compare viability of CNE-2 and CNE-2-miR-210 cells. (B) Results to assess and compare viability of CNE-2R and CNE-2R-miR-210-inhibitor cells. Data are the means \pm standard error of the mean, ${ }^{~} \mathrm{P}<0.05$ vs. 0 Gy. Three independent experiments were performed.

A

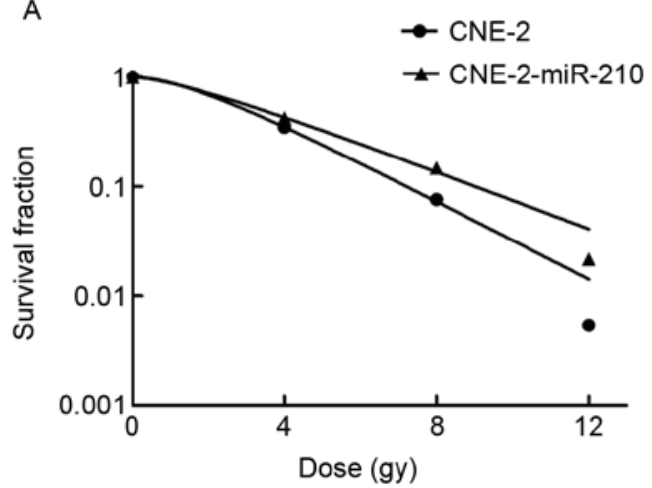

B

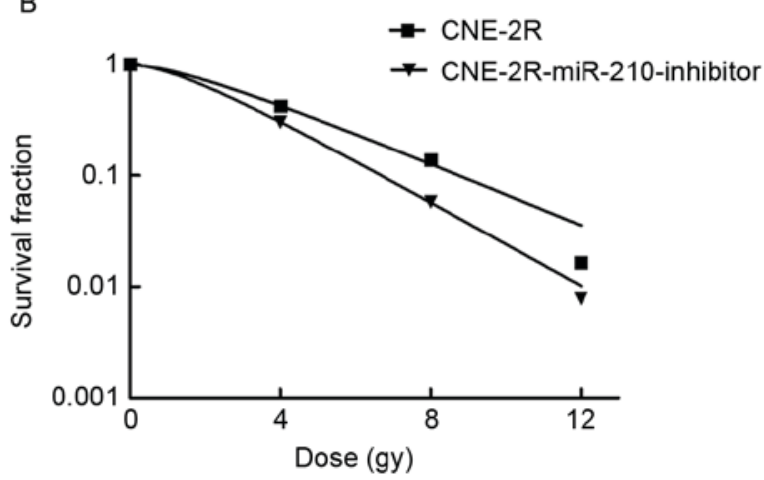

Figure 7. Survival fraction. (A) Survival fraction for CNE-2 and CNE-2-miR-210 cells treated with increasing doses of radiation. (B) Survival fraction for CNE-2R and CNE-2R-miR-210-inhibitor cells treated with increasing doses of radiation. Three independent experiments were performed.

have reported that miRNAs are involved in the control of DNA damage or its repair mechanisms $(19,20)$. In addition, miRNAs are involved in various malignant cell behaviors, including radioresistance (21-24). miR-205, miR-7, miR-100 and miR-101 have been reported to be associated with tumor radioresistance (25-28). For example, miR-218 is often absent in cervical cancer, which sensitizes human cervical cancer cells to radiotherapy by promoting apoptosis (29). miR-148b increases the radiosensitivity of non-Hodgkin lymphoma (NHL) cells via enhancing radiation-induced apoptosis, which reported that miR-148b serves a significant role in the response of NHL to radiation (30). miR-504 is downregulated following radiotherapy of NPC, which can be regarded as a new radioresistant biomarker to monitor the tumor response to radiation 
treatment (31). Taken together, these studies have indicated that miRNAs are crucial in mediating the radioresistance to cancer. However, there have been few reports of the possible role of miR-210 in radiation resistant tumor cells. Therefore, the objective of the present study was to investigate the possible correlation between miR-210 and the radiosensitivity of tumor cells.

The results demonstrated that miR-210 induced cell cycle arrest, and cells that had high expressions of miR-210 in the $\mathrm{S}$ phase were significantly decreased while the percentage of cells in $\mathrm{G}_{2} / \mathrm{M}$ phase increased. There are significant differences in the radiosensitivity of cells in the cell cycle. The radiosensitivity of the $G_{2} / M$ phase is high, and the $S$ phase is the most radioresistant (32). In addition, increased expression of miR-210 suppressed cell apoptosis. Similar to the trends observed for cell viability, the higher the expression level of miR-210, the higher the cell viability after irradiation. The colony formation assay confirmed that tumor cells with high levels of miR-210 were less sensitive to radiation. Based on these results, the expression of $\mathrm{miR}-210$ is inversely correlated with the radiosensitivity of tumor cells.

However, the radiation resistance mechanism of miR-210 remains unclear (33). It has been reported that vascular endothelial growth factor (VEGF) is one of the targets of miRNA-210 (34). VEGF can contribute to tumorigenesis, by promoting angiogenesis and enhancing the blood supply (35). Moreover, miR-210 has been reported to be the most highly induced miRNA in hypoxic cells (36), and hypoxia reduces the radiosensitivity of tumor cells both in vitro and in vivo (37). Previous studies have reported that some miRNAs can regulate the DNA damage response to radiation and participate in DNA repair pathways $(38,39)$, but the mechanisms involved in radioresistance, angiogenesis, apoptosis, cell cycle control and DNA damage/repair are still unknown. Further studies are needed to identify the binding sites of miR-210 and characterize signaling pathways of miR-210.

Taken together, the presented findings provide insight into improving tumor radiosensitivity, and strongly suggest that miR-210 expression is negatively associated with the radiosensitivity of tumor cells. In addition, the results demonstrated that miR-210 may be used to predict the therapeutic effects of radiotherapy in cancer patients, suggesting that miR-210 could be a prognostic biomarker for cancer patients with radiotherapy, and may provide novel insights into the identification of therapeutic targets.

\section{Acknowledgments}

The current work was supported by Natural Science Foundation Project of Chongqing (grant no. cstc2012jjA10138), and the Oncology of National Clinical Specialist Project (grant no. [2013] 544).

\section{References}

1. Tamura M, Ito $\mathrm{H}$ and Matsui $\mathrm{H}$ : Radiotherapy for cancer using X-ray fluorescence emitted from iodine. Sci Rep 7: 43667, 2017.

2. Serbanescu GL, Gruia MI, Bara M and Anghel RM: The evaluation of the oxidative stress for patients receiving neoadjuvant chemoradiotherapy for locally advanced rectal cancer. J Med Life 10: 99, 2017.
3. Yoon SM, Shaikh T and Hallman M: Therapeutic management options for stage III non-small cell lung cancer. World J Clin Oncol 8: 1-20, 2017.

4. Son SH, Choi KH and Kim SW: Dosimetric comparison of simultaneous integrated boost with whole-breast irradiation for early breast cancer. PLoS One 12: e0173552. 2017.

5. Zhang N, Liang SB, Deng YM, Lu RL, Chen HY, Zhao H, Lv ZQ, Liang SQ, Yang L, Liu DS and Chen Y: Primary tumor regression speed after radiotherapy and its prognostic significance in nasopharyngeal carcinoma: A retrospective study. BMC cancer 14: 136, 2014

6. Chen ZT, Liang ZG and Zhu XD: A Review: Proteomics in Nasopharyngeal Carcinoma. Int J Mol Sci 16: 15497-15530, 2015.

7. Chen MY, Jiang R, Guo L, Zou X, Liu Q, Sun R, Qiu F, Xia ZJ, Huang HQ, Zhang L, et al: Locoregional radiotherapy in patients with distant metastases of nasopharyngeal carcinoma at diagnosis. Chin J Cancer 32: 604-613, 2013.

8. Hutajulu SH, Kurnianda J, Tan IB and Middeldorp JM: Therapeutic implications of Epstein-Barr virus infection for the treatment of nasopharyngeal carcinoma. Ther Clin Risk Manag 10: 721-736, 2014.

9. Mendell JT and Olson EN: MicroRNAs in stress signaling and human disease. Cell 148: 1172-1187, 2012.

10. Pedersen CC, Refsgaard JC, Østergaard O, Jensen LJ, Heegaard $\mathrm{NH}$, Borregaard $\mathrm{N}$ and Cowland JB: Impact of microRNA-130a on the neutrophil proteome. BMC immunol 16: $70,2015$.

11. Li J, Dong G, Wang B, Gao W and Yang Q: miR-543 promotes gastric cancer cell proliferation by targeting SIRT1. Biochem Biophys Res Commun 469: 15-21, 2016.

12. Lee D, Sun S, Zhang XQ, Zhang PD, Ho AS, Kiang KM, Fung CF, Lui WM and Leung GK: MicroRNA-210 and endoplasmic reticulum chaperones in the regulation of chemoresistance in glioblastoma. J Cancer 6: 227-232, 2015

13. Li Y, Han W, Ni TT, Lu L, Huang M, Zhang Y, Cao H, Zhang HQ, Luo W and Li H: Knockdown of microRNA-1323 restores sensitivity to radiation by suppression of PRKDC activity in radiation-resistant lung cancer cells. Oncol Rep 33: 2821-2828, 2015.

14. Chan SY, Choy KW, Tsao SW, Tao Q, Tang T, Chung GT and Lo KW: Authentication of nasopharyngeal carcinoma tumor lines. Int J Cancer 122: 2169-2171, 2008.

15. Livak KJ and Schmittgen TD: Analysis of relative gene expression data using real-time quantitative PCR and the 2(-Delta Delta C(T)) Method. Methods 25: 402-408, 2001

16. Shi RC, Meng AF, Zhou WL, Yu XY, Huang XE, Ji AJ and Chen L: Effects of home nursing intervention on the quality of life of patients with nasopharyngeal carcinoma after radiotherapy and chemotherapy. Asian Pac J Cancer Prev 16: 7117-7121, 2015.

17. Guo P, Lan J, Ge J, Nie Q, Guo L, Qiu Y and Mao Q: MiR-26a enhances the radiosensitivity of glioblastoma multiforme cells through targeting of ataxia-telangiectasia mutated. Exp Cell Res 320: 200-208, 2014

18. Begg AC, Stewart FA and Vens C: Strategies to improve radiotherapy with targeted drugs. Nat Rev Cancer 11: 239-253, 2011.

19. Czochor JR and Glazer PM: microRNAs in cancer cell response to ionizing radiation. Antioxid Redox Signal 21: 293-312, 2014.

20. Metheetrairut $\mathrm{C}$ and Slack FJ: MicroRNAs in the ionizing radiation response and in radiotherapy. Curr Opin Genet Dev 23: 12-19, 2013

21. Su H, Jin X, Zhang X, Xue S, Deng X, Shen L, Fang Y and Xie C: Identification of microRNAs involved in the radioresistance of esophageal cancer cells. Cell Biol Int 38: 318-325, 2014.

22. Wang P, Zhang J, Zhang L, Zhu Z, Fan J, Chen L, Zhuang L, Luo J, Chen H, Liu L, et al: MicroRNA 23b regulates autophagy associated with radioresistance of pancreatic cancer cells. Gastroenterology 145: 1133-1143.e12, 2013.

23. Chun-Zhi Z, Lei H, An-Ling Z, Yan-Chao F, Xiao Y, Guang-Xiu W, Zhi-Fan J, Pei-Yu P, Qing-Yu Z and Chun-Sheng K: MicroRNA-221 and microRNA-222 regulate gastric carcinoma cell proliferation and radioresistance by targeting PTEN. BMC cancer 10: 367, 2010.

24. Yu J, Wang Y, Dong R, Huang X, Ding S and Qiu H: Circulating microRNA-218 was reduced in cervical cancer and correlated with tumor invasion. J Cancer Res Clin Oncol 138: 671-674, 2012.

25. Qu C, Liang Z, Huang J, Zhao R, Su C, Wang S, Wang X, Zhang R, Lee $\mathrm{MH}$ and Yang H: MiR-205 determines the radioresistance of human nasopharyngeal carcinoma by directly targeting PTEN. Cell Cycle 11: 785-796, 2012 
26. Lee KM, Choi EJ and Kim IA: microRNA-7 increases radiosensitivity of human cancer cells with activated EGFR-associated signaling. Radiother Oncol 101: 171-176, 2011.

27. Shi W, Alajez NM, Bastianutto C, Hui AB, Mocanu JD, Ito E, Busson P, Lo KW, Ng R, Waldron J, et al: Significance of Plk1 regulation by miR-100 in human nasopharyngeal cancer. Int J Cancer 126: 2036-2048, 2010.

28. Yan D, Ng WL, Zhang X, Wang P, Zhang Z, Mo YY, Mao H, Hao C, Olson JJ, Curran WJ and Wang Y: Targeting DNA-PKcs and ATM with miR-101 sensitizes tumors to radiation. PLoS One 5: e11397, 2010.

29. Yuan W, Xiaoyun H, Haifeng Q, Jing L, Weixu H, Ruofan D, Jinjin Y and Zongji S: MicroRNA-218 enhances the radiosensitivity of human cervical cancer via promoting radiation induced apoptosis. Int J Med Sci 11: 691-696, 2014.

30. Wu Y, Liu GL, Liu SH, Wang CX, Xu YL, Ying Y and Mao P: MicroRNA-148b enhances the radiosensitivity of non-Hodgkin's Lymphoma cells by promoting radiation-induced apoptosis. J Radiat Res 53: 516-525, 2012.

31. Zhao L, Tang M, Hu Z, Yan B, Pi W, Li Z, Zhang J, Zhang L, Jiang W, Li G, et al: miR-504 mediated down-regulation of nuclear respiratory factor 1 leads to radio-resistance in nasopharyngeal carcinoma. Oncotarget 6: 15995-16018, 2015.

32. Tengku Ahmad TA, Jaafar F, Jubri Z, Abdul Rahim K, Rajab NF and Makpol S: Gelam honey attenuated radiation-induced cell death in human diploid fibroblasts by promoting cell cycle progression and inhibiting apoptosis. BMC Complement Altern Med 14: 108, 2014.
33. In Lee S, Ji MR, Jang YJ, Jeon MH, Kim JS, Park JK, Jeon IS and Byun SJ: Characterization and miRNA-mediated posttranscriptional regulation of vitelline membrane outer layer protein I in the adult chicken oviduct. In Vitro Cell Dev Biol Anim 51: 222-229, 2015.

34. Liu SC, Chuang SM, Hsu CJ, Tsai CH, Wang SW and Tang CH: CTGF increases vascular endothelial growth factor-dependent angiogenesis in human synovial fibroblasts by increasing miR-210 expression. Cell Death Dis 5: e1485, 2014.

35. Goel HL and Mercurio AM: VEGF targets the tumour cell. Nat Rev Cancer 13: 871-882, 2013.

36. Osugi J, Kimura Y, Owada Y, Inoue T, Watanabe Y, Yamaura T, Fukuhara M, Muto S, Okabe N, Matsumura Y, et al: Prognostic impact of hypoxia-inducible miRNA-210 in patients with lung adenocarcinoma. J Oncol 2015: 316745, 2015.

37. Harriss-Phillips WM, Bezak E and Yeoh E: Monte Carlo radiotherapy simulations of accelerated repopulation and reoxygenation for hypoxic head and neck cancer. Br J Radiol 84: 903-918, 2011.

38. Gasparini P, Lovat F, Fassan M, Casadei L, Cascione L, Jacob NK, Carasi S, Palmieri D, Costinean S, Shapiro CL, et al: Protective role of miR-155 in breast cancer through RAD51 targeting impairs homologous recombination after irradiation. Proc Natl Acad Sci USA 111: 4536-4541, 2014.

39. Liu YJ, Lin YF, Chen YF, Luo EC, Sher YP, Tsai MH, Chuang EY and Lai LC: MicroRNA-449a enhances radiosensitivity in CL1-0 lung adenocarcinoma cells. PLoS One 8: e62383, 2013. 